\title{
BACTERIOLOGICAL STUDIES ON PASTEURELLA INFECTION IN SHEEP
}

\author{
Ahmed Moustafa Ahmed Moustafa \\ Animal Health Research Institute, Mansoura Provincial Laboratory
}

\begin{abstract}
A total of 51 samples (43 nasopharyngeal swabs and 8 lung tissues) were taken from 43 animals of private sheep flock at Dakahlia province some of which were showing respiratory manifestations, the examined include 30 lambs (8 emergency slaughtered, 14diseased and 8 apparently healthy) and 13 adult sheep (9 diseased and 4 apparently healthy). The bacteriological examinations revealed that $58.14 \%$ of examined animals were positive for pasteurella species, Mannheimia hemolytica (M.hemolytica) represent the most common isolates as $41.86 \%$ while $23.26 \%$ were infected with pasteurella multocida (P.multocida). Mixed infection with the isolated species was found as 6.98\%. Meanwhile the isolated species were pathogenic for mice. On the other hand, the sensitivity test in vitro for pasteurella specis proved that all examined isolates were sensitive for norfloxacine and enrofloxacine while $94.12 \%$ and $88.24 \%$ were sensitive for oxytetracycline and ciprofloxacine respectively, on the other hand all isolates were resistant for amoxacillin and gentamycin but $76.47 \%$ of the isolates were resistant for streptomycin and lincomycin.
\end{abstract}




\section{INTRODUCTION}

Pasteurella organisms has a wide host spectrum and cause epidemic and septicemic diseases of both animals and birds. It has been incriminated as a primary or secondary cause of pneumonia (enzootic pneumonia) (Gilmour and Angus, 1983). Concerning sheep, there is no doubt that pasteurellosis is one of the most important infectious diseases which causes economic loss not only due to high mortalities, but also due to loss in body weight of pasteurellosis recovered sheep (Winkler,1982). Jubb et al.,(1985) mentioned that the pasteurella species were a part of normal flora of the nasopharynx of various animals, and stress factors such as shipping and climatic changes have been incriminated as an important predisposing for the proliferation of these organisms in the nasal cavity before the lung lesions were produced. Other stress factors were transportation, overcrowding, poor ventilation, heat and gathering handling (Brogden et al., 1998) .Pasteurella organisms transmitted from carrier sheep through contaminated air, water, feed and equipments into susceptible sheep by inhalation and by ingestion (Jensen and Swift, 1982). The ovine pneumonic pasteurellosis affecting all ages with high prevalence in nursing and feedlot lambs (Jensen and Swift, 1988). The pasteurellosis may have an acute, subacute and chronic course (Nesbit et al.,1994).

Investigation of pasteurella microorganisms that affect the respiratory system of sheep is very important as it enable us to evaluate the role played by these organisms ,therefore the present work was designed to enlighten the following aspects: 
Bacteriological Studies On Pasteurella Infection In Sheep.

1- Prevalence of pasteurella species in sheep suffering from respiratory disorders at Dakahlia province.

2- Identification of pasteurella microorganisms by their morphology and biochemical activities.

3- Determination of the pathogenicity of pasteurella isolates.

4- Testing the susceptibility of the isolates to some antimicrobial agents.

\section{MATERIAL AND METHODS}

The present investigation was done on 43 adult sheep and lambs from private sheep flock suffering from respiratory manifestations at Dakahlia Province as showed in Table (1).

Table (1): Number of examined animals.

\begin{tabular}{|c|c|c|c|c|}
\hline Animal & Emergency slaughtered & Diseased & Apparently healthy & Total \\
\hline Lamb & 8 & 14 & 8 & 30 \\
\hline Adult sheep & - & 9 & 4 & 13 \\
\hline Total & 8 & 23 & 12 & 43 \\
\hline
\end{tabular}

\section{Samplings:}

A total of 51 samples (43 nasopharyngeal swabs from all examined sheep and 8 lung samples from emergency slaughtered lambs) were collected. The samples were collected under aseptic conditions in sterile swabs and plastic bags, and transported in ice box to the laboratory without delay. 


\section{Bacteriological examination:}

\section{Culturing:}

Nasopharyngeal swabs were inoculated into sterile nutrient broth and incubated at $37^{\circ} \mathrm{C}$ for 24 hours, then subcultured onto DAS medium (Crystal Violet Cobalt Agar) which used as a selective medium for isolation of Pasteurella species and incubated at $37^{\circ} \mathrm{C}$ for $24-48$ hours.

Surface of lung tissue samples were sterilized with a hot spatula then incised with sterile scalpel and the specimen were taken by sterile platenium loop and inoculated into sterile DAS medium, incubated at $37^{\mathrm{O}} \mathrm{C}$ for 24- 48 hours (Cruickshank et al., 1975)

\section{Identification:}

The resultant colonies were identified by their morphology and biochemical activities according to Quinn et.al., (2002).

Pathogenicity of isolated Pasteurella species to mice (Wessman (1964).

Bacterial suspension for each 17 Pasteurella isolate (11 M.hemolytica and 6 P.multocida) were prepared by plate washing technique. $0.1 \mathrm{ml}$ of bacterial suspension of isolate $\left(1.5 \times 10^{8} \mathrm{CFU}\right)$ was injected intraperitoneally for Swiss albino mice 16-20 grams weight ( 2 mice used for each isolate), 5 mice used as control. The dead mice were subjected to postmortem examination, blood smears were prepared from heart blood of dead mice,stained with Leshiman's stain to notice the characteristic bipolarity of Pasteurella and reisolation of inoculated Pasteurella strains from spleen and heart blood of dead mice were carried out. 
Bacteriological Studies On Pasteurella Infection In Sheep.

\section{Antimicrobial sensitivity test:}

The sensitivity of the recovered isolates of pasteurella species to antibacterial agents were done by disc diffusion method according to Cruickshank et al., (1975) and koneman et al., (1992) (10)discs of antimicrobial agents were used in the test, which produced by oxoid .

\section{RESULTS}

Table (2): Prevalence of Pasteurella species in examined sheep .

\begin{tabular}{|c|c|c|c|c|c|c|c|}
\hline \multirow{2}{*}{$\begin{array}{c}\text { Examined } \\
\text { animals }\end{array}$} & \multirow{2}{*}{$\begin{array}{c}\text { No. of } \\
\text { samples }\end{array}$} & \multicolumn{2}{|c|}{ Pasteurella species } & \multicolumn{2}{|c|}{ Mannheimia hemolytica } & \multicolumn{2}{|c|}{ Pasteurella multocida } \\
\hline & & $\begin{array}{l}\text { Positive } \\
\text { samples }\end{array}$ & $\%$ & $\begin{array}{l}\text { Positive } \\
\text { samples }\end{array}$ & $\%$ & $\begin{array}{l}\text { Positive } \\
\text { samples }\end{array}$ & $\%$ \\
\hline $\begin{array}{l}\text { Emergency } \\
\text { Slaughtere } \\
\text { d lambs }\end{array}$ & 8 & 6 & 75 & 5 & 62.5 & 2 & 25 \\
\hline $\begin{array}{l}\text { Diseased } \\
\text { lambs }\end{array}$ & 14 & 9 & 64.29 & 7 & 50 & 3 & 21.43 \\
\hline $\begin{array}{l}\text { Apparently } \\
\text { healthy } \\
\text { lambs }\end{array}$ & 8 & 2 & 25 & - & - & 2 & 25 \\
\hline $\begin{array}{l}\text { Diseased } \\
\text { adult sheep }\end{array}$ & 9 & 5 & 55.56 & 5 & 55.56 & 1 & 11.11 \\
\hline $\begin{array}{l}\text { Apparently } \\
\text { healthy } \\
\text { adult sheep }\end{array}$ & 4 & 3 & 75 & 1 & 25 & 2 & 50 \\
\hline Total & 43 & 25 & 58.14 & 18 & 41.86 & 10 & 23.26 \\
\hline
\end{tabular}

N.B. 3 animals(6.98\%) showed mixed infection with Mannheimia hemolytica and Pasteurella multocida

Kafrelsheikh Vet. Med. J. Vol. 7 No. 1 (2009) 
Ahmed Moustafa Ahmed Moustafa,

Table (3): Prevelance of Pasteurella species in examined samples

\begin{tabular}{||c||c||c|c||c|c||}
\hline \multicolumn{1}{|c||}{ Type of sample } & \multicolumn{2}{c||}{$\begin{array}{c}\text { Manheimia hemolytica } \\
\text { No. of }\end{array}$} & \multicolumn{2}{c||}{ Pasteurella multocida } \\
\cline { 3 - 6 } & Pomples & $\begin{array}{c}\text { Positive } \\
\text { samples }\end{array}$ & $\%$ & $\begin{array}{c}\text { Positive } \\
\text { Samples }\end{array}$ & $\%$ \\
\hline \hline Lung of slaughtered of lambs & 8 & 5 & 62.5 & 2 & 25 \\
\hline $\begin{array}{c}\text { Nasopharyngeal swabs of } \\
\text { slaughtered lambs }\end{array}$ & 8 & 4 & 50 & 2 & 25 \\
\hline $\begin{array}{c}\text { Nasopharyngeal swabs of diseased } \\
\text { lambs }\end{array}$ & 14 & 7 & 50 & 3 & 21.43 \\
\hline $\begin{array}{c}\text { Nasopharyngeal swabs of } \\
\text { apparently healthy lambs }\end{array}$ & 8 & - & - & 2 & 25 \\
\hline $\begin{array}{c}\text { Nasopharyngeal swabs of diseased } \\
\text { adult sheep }\end{array}$ & 9 & 5 & 55.56 & 1 & 11.11 \\
\hline $\begin{array}{c}\text { Nasopharyngeal swabs of } \\
\text { apparently healthy adult sheep }\end{array}$ & 4 & 1 & 25 & 2 & 50 \\
\hline \hline Total & 51 & 22 & 43.14 & 12 & 23.53 \\
\hline
\end{tabular}

Table (4): Sensitivity of Pasteurella species isolates from sheep samples $(n=34)$ to some antimicrobial agents.

\begin{tabular}{|c||c||c|c||c|c||}
\hline \multirow{2}{*}{ Chemotherabeutic } & \multirow{2}{*}{\begin{tabular}{c}
\multirow{2}{*}{ Disc } \\
potency
\end{tabular}} & \multicolumn{2}{c|}{ Sensitive isolates } & \multicolumn{2}{c|}{ Resistant isolates } \\
\cline { 2 - 6 } & No. & $\%$ & No. & $\%$ \\
\hline \hline \multirow{2}{*}{ Oxytetracycline } & $30 \mathrm{ug}$ & 32 & 94.12 & 2 & 5.88 \\
\hline Ciprofloxacine & $30 \mathrm{ug}$ & 30 & 88.24 & 4 & 11.76 \\
\hline Norfloxacine & $10 \mathrm{ug}$ & 34 & 100 & - & - \\
\hline Enrofloxacine & $5 \mathrm{ug}$ & 34 & 100 & - & - \\
\hline Streptomycin & $10 \mathrm{ug}$ & 8 & 23.53 & 26 & 76.47 \\
\hline Sulfamethaxole & $23.75 \mathrm{ug}$ & 10 & 29.41 & 24 & 70.59 \\
\hline Trimethprim & $5 \mathrm{ug}$ & 12 & 35.29 & 22 & 64.71 \\
\hline Gentamycin & $10 \mathrm{ug}$ & - & - & 34 & 100 \\
\hline Lincomycin & $15 \mathrm{ug}$ & 8 & 23.53 & 26 & 76.47 \\
\hline Amoxacillin & $25 \mathrm{ug}$ & - & - & 34 & 100 \\
\hline
\end{tabular}

Kafrelsheikh Vet. Med. J. Vol. 7 No. 1 (2009) 


\section{DISCUSSION}

Pneumonic pasteurellosis is one of the most important diseases of sheep throughout the world. Both Manheimia hemolytica and Pasteurella multocida have been associated with the disease (Oden Daal and Henton 1995).

The overall prevalence of Pasteurella species in examined sheep of this study was $58.14 \%$. which was higher than that recorded by Andrawis (2001) but lower than that found by Black (1997). The high incidence of Pasteurella species may be attributed to the nature of breeding which mainly grazing of the examined sheep flock and also the transportation from place to another which increase the propagation of infection beside its act as predisposing factor for Pasteurellosis.

Also the obtained results proved that the lambs were more susceptible to the infection than adults and this was agreed with Gilmour and Gilmour (1989) and Abd El Rahiem (2002) who recorded the same result in Menofia, Damietta and Kafr El Sheikh Provinces, Egypt. On other hand Frank (1982), Baysal and Guler (1992) and El Beskawy (2005) reported that adult sheep were higher in rate of isolation than lambs and they attributed this to that, the carrier state increased in older age than young.

The results reported in (Table 3) showed that the Manheimia hemolytica was isolated as $25 \%$ from nasopharyngeal swabs of apparently healthy adult sheep and not isolated from apparently healthy lambs. These results were in agreement with that reported by Gilmour and Angus (1983) and Davies (1985) who stated that M. hemolytica is a part of normal nasal microflora of healthy sheep, but the obtained results were 
higher than that recorded by Hussein et.al., (2000) and El Beskawy (2005). Meanwhile Pasteurella multocida was observed as $50 \%$ and $25 \%$ in nasal swabs of apparently healthy adult sheep and lambs respectivily which agreed with Chandrasekaran et.al., (1991) who recorded that $P$. multicoda was found as a respiratory common pathogen in sheep in temperate areas but may be of greater importance in tropical areas. On the other hand the detected results were higher than reported by Hamdy et .al., (1989) and Elyas (1993). From nasopharyngeal swabs of diseased adult sheep M. hemolytica was isolated as $55.56 \%$ while it was $50 \%$ in diseased lambs. Pasteurella multocida was recorded in nasal swabs of diseased adult sheep as $11.11 \%$ while diseased lambs recorded $21.43 \%$ .The obtained results were higher than that recorded by Kaya and Kirkan (1999) and Abd El Rahiem ( 2002 ). On the other hand Abd El- Latif and El Dessouky (2006) stated that Pasteurella multocida and $M$. hemolytica were found in clinically diseased lambs in Dakahlia province as 17.14 and $5.71 \%$ respectively.

Concerning lung samples of slaughtered lambs, this study declared that the Pasteurella species were isolated as $87.5 \%$ ( M. hemolytica 62.5 $\%$ and Pasteurella

multocida $25 \%$ ), the obtained results were lower than that recorded by $\boldsymbol{E l}$ Beskawy (2005) who declared that Pasteurella species isolated as 99.99\% (M. hemolytica $80.88 \%$ and Pasteurella multocida $19.11 \%$ ), also Hatem et al., (2003) isolated Pasteurella multocida as $30 \%$ and $\boldsymbol{E l}$ Sukhon (1995) isolated Pasteurella hemolytica in Jordon as $36 \%$.

The present study revealed that, all tested isolates of Pasteurella speices were pathogenic to injected mice (the death have been occurred within 72 hours post inoculation). 
Regarding to the sensitivity test, Table 4 showed that both tested isolates of Pasteurella hemolytica and pasteurella multocida were sensitive to n.orfloxacine and enrofloxacine (100\%), oxytetracycline $(94.12 \%)$ and ciprofloxacine $(88.24 \%)$. The isolates were resistant to gentamycin and amoxicillin with percentage 100\%, streptomycin and lincomycin $(76.47 \%)$, sulfamethaxole $(70.59 \%)$ and trimethprim $(64.71 \%)$. These results were some what differ from Mackie et.al.,(1995) who found that $M$. hemolytica where sensitive to oxytetracycline ,pencillin, amoxicillin, cephalothin, erythromycin and resistant to Sulfamethoxole, trimethprim, lincomycin, streptomycin, neomycin, gentamycin and kanamycin, While Lin et al., (2001) showed that both $M$. hemolytica and P. multocida isolated from chicken were sensitive to ceftiofur, amoxicillin, lincomycin and spectinomycin, moderately sensitive to tetracyclin and slightly sensitive to chloramphenicol. Also Talab (2002) found that Pasteurella hemolytica were sensitive to ciprofloxacine $(92.5 \%)$ and gentamycin $(20 \%)$ and in the same time resistant to neomycin. So sensitivity test for drug choice to treatment of Pasteurella infection must be done.

\section{REFERENCES}

- Abd El-Latif, M.M. and El-Dessouky, S.A. (2006): Studies on some bacterial causes and blood serum biochemical changes of respiratory affections in lambs . Assiut Vet. Med. J. 52 (108) : 170-182.

- Abd El-Rahiem, M.M.Y.(2002): Some immunological studies on Pasterurellosis in sheep.Ph. D. Thesis, infectious diseases ,Fac. Vet. Med. Cairo University

- Andrawis, A.H. (2001): Bacteriological studies on respiratory affections in sheep and goats. Ph.D. Thesis bacteriology,Fac. Of Vet. Med. Cairo University . 
- Baysal, T. and Guler, L.(1992): Isolation of bacteria from enzootic Pneumoniain lambs and kids in konya region. Veterinarium 3(1): 1-5 .

- Black, H. (1997): Pasteurella isolates from sheep pneumonia cases in New Zealand . Surveillance (Wellington), 24(3) : 5-8 .

- Blanco -Viera; Trigo,F. J; Jarmillo - Meza, L. and Aguila - Romero, F. (1995): Serotypes of P.multocida and P.haemolytica isolared from pneumonic lesions in cattle and sheep Revista - Latino - American de microbiologia 37 (2) 121-126.

- Brogden, K. A. ; Lehmkuhl,H.D. and Cutlip, R. C. (1998): P. haemolytica complicated respiratory infections in sheep and goats. Vet. Res., $29(3-4): 233-254$.

- Chandrasekaran, S.; Hizat,K.; Saad,Z.;Johar, M.Y. and Yeap,P, C. (1991) : Evaluation of combined Pasteurella vaccine in control of sheep pneumonia. Br. Vet. J. 147 : 437 - 443.

- Cruickshank, R.; Duguid, J.R.; Marmion, B.D. and Swain, R.H.A. (1975): Medical Microbiology. The Practice of Medical Microbiology VIII $11^{\text {th }}$ and $12^{\text {th }}$ Ed., Churchill Living Stone Edinburgh, London and New York.

- Davies,D.H.(1985): Aetiology of pneumonia of young sheep infection and Imnunity in farm animals. Basal, Switzerland, S.Karger(1985) 229-248.

- El-Beskawy, M.A.A. (2005): Some studies on sheep Pasteurellosis, M.D., thesis Department of Infectious Diseases, Fac. Of Vet. Med., Benha University.

- El-Sukhon, S. N. (1995): Virulence factors in bacterial isolates from Pneumonic sheep lungs in Northern Jordan. Assuit Vet. Med. J. 33 (66): 102-111.

- Elyas, A. H.(1993): Some studies on sheep pneumonia of bacterial and Fungal origin. Assuit Vet. Med. J. 29 (58): 89-95. 
- Frank,G.H.(1982): Serotypes of P.haemolytica in sheep in MidWestern United States. Am. J. Vet. Res.Vol. 43 No 11 Nov. (1982).

- Gilmour, N.J.L. and Angus, K.W. (1983): Pasteurellosis. Disease of Animal Diseases Research Association. The Meredun institute, Edinburgh, 3-8

- Gilmour, N.J.L. and Gilmour,J.S.(1989): In pasteurella and Pasteurellosis edited by aldlam C and Rutter J.M.,Academic Press, London, p.223.

- Hamdy, M.;El-Rahman, H.A.; S.Makeen,S.; Fadl, H. and nouman, T. (1989): Incidence of pasteurellae among slaughtered sheep and its effect on meat quality. Assuit. Veterinary Medical Journal 21: 42, 93 100 .

- Hatem, M. E.; Mona, S. Zaki.; Osman, A. H.and Mona El-shabrawy (2003): Bacteriological, histopathological and clinicopathological Studies on respiratory affection in sheep and goat in Egypt .J. Egypt Vet. Med. Ass. 1:97-109.

- Hussein, A.Z.; Fayed, A. A. ; Gergis, S. M.; Aboul Saoud, S. M. and Diab, R. A. (2000): Development of combined clostridial and pasteurella Vaccine for sheep . $5^{\text {th }}$ Vet . Med. Zag. Conference (1214Sept. Sharm El-sheikh Pp 158-166.

- Jensen and swift (1982): Diseases of sheep $2^{\text {nd }}$ Edition.

- Jensen and swift (1988): Jensen and Swift's diseases of sheep. $3^{\text {th }}$ Ed. Blackwell Scientific Publication, Oxford, London.

- Jubb, K.V.F.; Kennedy, P.C. and Palmer, N.(1985): Pasteurellosis in farm Animals .In pathology of domestic animals Vol. 2 : 487 London, Academic Press.

- Kaya,O. and Kirkan,S.(1999): Biotyping and antimicrobial susceptibility of P. haemolytic strains isolated from nasal cavity of normal and pneumonic sheep in Aydin region. Bornova Veteriner. Kontrol-ve Arastrima. Enstituis. Dergisi(1999) 24 (38) 21-25. 
- Koneman, E.W. ;Allen,S.D. ;Jan, W.M. ;Schrechn, Berrjer, P.C. and Winn, T.R. (1992): Colour atlas and textbook of diagnostic Microbiology $4^{\text {th }}$ ed. J.B. Lippicntt Co. Philadelphia U.S.A.

- Lin, M.Y.;Lin, K.J.; Lan, Y.C.;Liaw, M.F. and Tung, M.C.(2001): Pathogenicity and drug Susceptibility of the pasteurella anatis isolated in chickens in Taiwan. Avain Dis.45(3) : 655-8.

- Mackie,J.T.; Barton, M.; Hindmarch, M. and Holswoeth, I. (1995): P.haemolytica septicaemia in sheep . Austrialian Vet. Journal. 72 (12): 474 .

- Nesbit,J.W;Bastainello, S.S. and Bath. G (1994): In ovine and caprine Pasteurellosis in atext book of infectious diseases of live stock with Special reference to southern Africa chapter 143:1184-1191 oxford University press . South Africa.

- Oden Daal , M.W. and Henton, M.M (1995): The distribution of P. haemolytica serotypes among cattle, sheep and goats in south Africa and their association with disease On Derstepoort Journal of Vet. Research 62(4) 223-226.

- Quinn P.J.;Markey,B. K.;Carter,M.E.;Donnelly,W.J.C. and Leonard, F.C. (2002): Veterinary Microbiology and Microbial Diseases. $1^{\text {st }}$ Ed. Mpg Books Ltd, Bodmin, Cornwall, Great Britain.

- Talab, S.E.A. (2002): Microbiological studies on pasteurella haemolytica in Sheep. M.D. thesis Department of microbiology, Fac. Of Vet. Med., Zagazig University.

- Wessman, G.E. (1964): Interrelation of smooth and non -smooth variant in dissociation of Pasteurella haemolytica. J. Bact., 88: 325360.

- Winkler, J.K. (1982): Farm animal health and disease control . $2^{\text {nd }}$ Ed. London. 


\section{دراسات بكتريولوجية للإصابة بالباستريلا في الأغنام

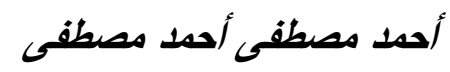

معهز بحوث صحة الحيوان - فرع المنصورة

أجريت الدراسة على 51 عينة أخذت من 43 من الأغنام والحملان في قطيع من الأغنام فى محافظة الدقهلية مصابة بأعر اض تتفسية وتتمل 30 حمل (8 ذبحت اضطر اريا و14 مصابة و8 سليمة ظاهريا) وكذلك 13 من الأغنام (9 مصابة و4 سليمة ظاهريا) وقد أظهر الفحص البكتريولوجى ان58.14\% من الحيو انات الدفحوصة إيجابية لميكروب الباستر لا. حيث وجد أن نسبة كبيرة (41.86\%) من تلك الحيو انات مصابة بميكروب المانهيميا هيمولتكا بينما 23.26\% مصابة بميكروب الباستر لا مالتوسيدا وفى الوقت نفسه وجد أن 6.98\% من هذه الحيو انات مصابة بكل منهما ومن ناحية أخرى وجد أن تللك المعزولات مميتة للفئران الا لبنو وبإجر اء اختبار الحساسية لتلك الميكروبات المعزولة وجد أن جميع المعزو لات المختبرة حساسة لنورفلوكساسين و الانروفلوكساسين، بينما 94.12\%، 88.24\% من المعزو لات حساسة للأوكسى تتز اسيكيلين و السبروفلوكساسين على التو الى و على النقيض من ذلك وجد أن جميع المعزو لات مقاومة للأموكساسلين و الجينتاميسين ولكن 76.47 من المعزو لات المختبره مقاومة للإستربتومايسن و اللنكومايسن. 